\title{
Pendidikan dan Karakter Mahasiswa di Perguruan Tinggi
}

\author{
Luhut Mawardi Sihombing
}

Prodi Pendidikan Agama Kristen, STT Renatus Pematang Siantar

\begin{abstract}
Abstrak
Pendidikan merupakan kunci utama strategi pembentukan karakter bangsa. Salah satu strategi pembangunan karakter pada mahasiswa, dapat dilakukan melalui kegiatan kemahasiswaan. Dalam kegiatan kokurikuler dan/atau kegiatan ekstra-kurikuler, perlu dikembangkan suatu proses pembiasaan dan penguatan dalam rangka pengembangan karakter. Kegiatan ekstrakurikuler dapat diselenggarakan melalui kegiatan olahraga dan seni dalam bentuk pembelajaran, pelatihan dan kompetisi. Berbagai kegiatan olahraga dan seni tersebut diorientasikan terutama untuk penanaman dan pembentukan sikap, perilaku dan kepribadian para pelaku olahraga atau seni agar menjadi manusia Indonesia berkarakter. Kegiatan ekstra-kurikuler yang diselenggarakan oleh gerakan pramuka, misalnya, dimaksudkan untuk mempersiapkan generasi muda sebagai calon pemimpin bangsa yang memiliki watak, kepribadian dan akhlak mulia serta keterampilan hidup prima.
\end{abstract}

Katakunci : Pendidikan, Karakter dan Mahasiswa

\begin{abstract}
Education is a main key of character building for Indonesian. One of the strategy in building students character is by student-based activities.Therefore, in every students activity, such as; co-curricula and extra-curricula should contains enrichment and enhencement of character building. In such an extra curricula, can be done by sport activity, arts, and other related activities of learning. All the selected activities aim to nurturing Indonesian students to own attitide, behave, that are sharpened to become characterized person. In such an extra curricula of Pramuka aims to build the strong character for the students for the purpose of their opportunity to be a leader of Indonesia country in the future, for this reason they should possess good character and skill in the form of soft skill and hard skill.
\end{abstract}

Keywords: Education, Character and students

\section{PENDAHULUAN}

Menurut Peraturan Pemerintah RI No.30 tahun 1990 Mahasiswa adalah peserta didik yang terdaftar dan belajar di Perguruan Tinggi tertentu dan menurut Kamus Besar Bahasa Indonesia, 1989 Mahasiswa adalah orang yang belajar di Perguruan Tinggi sedangkan menurut Knopfemacher (dalam Suwono, 1978) mahasiswa adalah merupakan insan-insan calon sarjana yang dalam keterlibatannya dengan perguruan tinggi, dididik dan di harapkan menjadi calon-calon intelektual.

Mahasiswa pada dasarnya merupakan subjek atau pelaku di dalam pergerakan pembaharuan atau subjek yang akan menjadi generasi-generasi penerus bangsa dan membangun bangsa dan tanah air ke arah yang lebih baik. Mahasiswa dianggap sebagai 'agent of change' atau agen perubahan

104 | Korespondensi mengenai artikel dapat dilakukan kepada: Luhut Mawardi Sihombing, Institut Agama Kristen Negeri

Tarutung, Jl. Raya Tarutung-Siborong KM 11, Silangkitang, Sipoholon, Tapanuli Utara (22452), Indonesia

e-mail Corresponding: luhutsihombing63@gmail.com 
yang menjadi pelaksana perubahan dan pembaharuan setiap sisi kehidupan untuk menciptakan suatu kondisi yang baik dalam kehidupan berbangsa sehingga menghasilkan suatu situasi yang didambakan oleh setiap bangsa, yaitu kesejahteraan setiap rakyat.

Di jaman sekarang ini, mahasiswa hanya disibukkan dengan seluruh kegiatan kuliah (kegiatan intra dan extra kampus) yang memberi corak yang sangat berwarna dan beragam dan tanpa disadari pengkayaan ini akan membawa mahasiswa menjadi sosok dengan jati diri yang beragam. Mahasiswa yang ikut dalam kegiatan intra atau extra kampus terkadang terjebak pada suatu atmosfer yang mereka anggap membawa mereka dalam suasana kebebasan yang benar-benar bebas. sebagian mahasiswa tersebut memanfaatkan bahwa keaktifan mereka dalam organisasi intra dan ekstra kampus boleh besikap bebas dan sudah merasa sebagai penguasa yang menguasai kampus.

Dalam realita yang kita temui lebih banyak mahasiswa yang tidak sadar dan tidak memiliki karakter sebagai mahasiswa sehingga bermunculanlah mahasiswa-mahasiswi yang tidak memiliki perilaku yang baik, seperti mahasiswa yang tidak memiliki sopan santun kepada para dosen, mahasiswa yang lebih menyukai hidup dengan bebas, mengonsumsi obat-obatan terlarang, pergaulan bebas antara mahasiswa dengan mahasiswi, berdemonstrasi dengan tidak mengikuti peraturan yang berlaku bahkan hal terkecil seperti menyontek disaat ujian.

Sudah saatnya dilakukan sebuah penyeimbangan kehidupan mahasiswa antara dunia perkuliahan dan pengkayaan diri mahasiswa melalui kegiatan intra dan extra kampus untuk memantapkan mahasiswa dalam menghadapi dunia nyata kelak. pembentukan karakter bukan hanya milik dan tugas mahasiswa semata dan ia harus mencari sendiri tetapi juga menjadi suatu tantangan bagi civitas academika

Melihat masalah-masalah yang telah dijelaskan diatas, maka penulis merasa perlu untuk menuliskan makalah ini. Makalah yang berjudul "Mahasiswa Berkarakter Untuk Membentuk Pendidikan Dan Kehidupan Bangsa Yang Lebih Baik" yang diharapkan dapat menjadi bahan rujukan dan masukan bagi pembaca khususnya bagi mahasiswa Indonesia sehingga bisa tercipta generasi mahasiswa yang lebih baik.

\section{PEMBAHASAN}

Mahasiswa adalah peserta didik yang terdaftar dan belajar di perguruan tinggi tertentu (Peraturan Pemerintah RI No.30 tahun 1990). Mahasiswa adalah orang yang belajar di perguruan tinggi (Kamus Besar Bahasa Indonesia, 1989).

Menurut Sarwono (1978) mahasiswa adalah setiap orang yang secara resmi terdaftar untuk mengikuti pelajaran di perguruan tinggi dengan batas usia sekitar 18-30 tahun. Mahasiswa merupakan suatu kelompok dalam masyarakat yang memperoleh statusnya karena ikatan dengan 
JURNAL CHRISTIAN HUMANIORA

Vol.4, No.1, May 2020, pp. 104-112

p-ISSN: 2598-6317- e-ISSN: 2599-196

perguruan tinggi. Mahasiswa juga merupakan calon intelektual atau cendekiawan muda dalam suatu lapisan masyarakat yang sering kali syarat dengan berbagai predikat.

Mahasiswa menurut Knopfemacher (dalam Suwono, 1978) adalah merupakan insan-insan calon sarjana yang dalam keterlibatannya dengan perguruan tinggi, dididik dan di harapkan menjadi calon-calon intelektual.

Berdasarkan beberapa pengertian diatas dapat disimpulkan bahwa Mahasiswa adalah sekumpulan manusia intelektual yang belajar diperguruan tinggi yang akan bermetamorfosa menjadi penerus tombak estafet pembangunan di setiap Negara, yang dengan itelegensinya diharapkan bisa mendobrak pilar-pilar kehampaan suatu negara dalam mencari kesempurnaan kehidupan berbangsa dan bernegara, serta secara moril akan dituntut tanggung jawab akdemisnya dalam menghasilkan "buah karya" yang berguna bagi kehidupan lingkungan.

Idealnya, mahasiswa haruslah memiliki sifat yang terpuji karena mahasiswa merupakan generasi penerus yang nantinya akan melanjutkan tongkat estafet pembangunan bangsa. Mahasiswa merupakan kader-kader pemimpim masa depan yang nantinya akan memimpin bangsa. Dengan demikian untuk mendapatkan pemimpin yang berkualitas mahasiswa haruslah memiliki karakter yang baik, sehingga kedepannya dapat memimpin bangsa menjadi lebih baik. Mahasiswa dengan karakter yang baik inilah yang nantinya diharapkan untuk mengubah keadaan bangsa yang semakin memprihatinkan ini menjadi bangsa yang sejahtera dimana semua penduduknya dapat hidup dengan lebih baik lagi.

\section{Metodology}

Penelitian yang telah dilakukan merupakan penelitian kwalitatif dengan pendekatan deskriptif kwalitatif, dimana data dikumpulkan dengan teknik trianggulasi yakni dengan observasi, angket, interviu, dan teknik dokumentasi, untuk tujuan memperkaya data hingga mencapai temuan yang sebenar-benarnya. Populasi dan sampel penelitian sebagai subjek penelitian (informant) adalah mahasiswa semester 1 tahun akademik 2018-2019 dari 2 perguruan tinggi yakni IAKN Tarutung dan STT Renatus Pematang Siantar. Selanjutnya technique of sampling dilakukan dengan cara random sampling maka terpilihlah 100 mahasiswa IAAKN Tarutung dan 100 mahasiswa STT Renatus Pematang Siantar, maka total sample penelitian menjadi 200 mahasiswa.

Analisis data dilakukan dengan deskripsi kwalitatif yakni dengan mengurai data secara detail dalam bentuk teks mendalam, baik yang bersumber dari observasi, angket, interviu dan dokumendokumen yang ada.

Kemudian, hasil analisis data ditampilkan (data display) dalam bentuk laporan hasil penelitian yang kemudian dikerucutkan menjadi temuan penelitian dan simpulan. Laporan hasil penelitian dan temuan penelitian tersebut akan diangkat dalam pembahasan pada artikel ini. 


\section{HASIL DAN TEMUAN PENELITIAN}

Untuk menjembatani antara hasil dan temuan penelitian dengan teori dan kenyataan di lapangan, maka penulis perlu membuat batasan dan rumusan permasaalahan pada penelitian yang dilakukan. Adapun batasan permasalahan adalah segala haal yang erkait dengan kemerosotan perilaku dan karakter mahasiswa sebagai akibat kurangnya penyuluhan-penyuluhan tentang narkoba oleh tim penyuluh dari pihak-pihak yang berkompeten di bidang itu. Rumusan masalah adalah : "Bagaimanakah bentuk-bentuk pemerosotan sikap dan karakter mahasiswa sebagai bias dari kurangnya penyuluhan dari tim penyuluh serta bagaimana mengatasinya?"

Karakter berasal dari bahasa Yunani yang berarti "to mark" atau menandai dan memfokuskan bagaimana mengaplikasikan nilai kebaikan dalam bentuk tindakan atau tingkah laku, sehingga orang yang tidak jujur, kejam, rakus dan perilaku jelek lainnya dikatakan orang berkarakter jelek. Sebaliknya, orang yang perilakunya sesuai dengan kaidah moral disebut dengan berkarakter mulia.

Pengertian karakter menurut Pusat Bahasa Depdiknas adalah "bawaan, hati, jiwa, kepribadian, budi pekerti, perilaku, personalitas, sifat, tabiat, temperamen, watak". Adapun berkarakter adalah berkepribadian, berperilaku, bersifat, bertabiat dan berwatak".

Menurut Tadkiroatun Musfiroh (UNY, 2008), karakter mengacu kepada serangkaian sikap (attitudes), perilaku (behaviors), motivasi (motivations) dan keterampilan (skills).

Karakter mulia berarti individu memiliki pengetahuan tentang potensi dirinya, yang ditandai dengan nilai-nilai seperti reflektif, percaya diri, rasional, logis, kritis, analitis, kreatif dan inovatif, mandiri, hidup sehat, bertanggung jawab, cinta ilmu, sabar, berhati-hati, rela berkorban, pemberani, dapat dipercaya, jujur, menepati janji, adil, rendah hati, malu berbuat salah, pemaaf, berhati lembut, setia, bekerja keras, tekun, ulet/gigih, teliti, berinisiatif, berpikir positif, disiplin, antisipatif, inisiatif, visioner, bersahaja, bersemangat, dinamis, hemat/efisien, menghargai waktu, pengabdian/dedikatif, pengendalian diri, produktif, ramah, cinta keindahan (estetis), sportif, tabah, terbuka, tertib.

Dari temuan penelitian didapat bahwa individu juga memiliki kesadaran untuk berbuat yang terbaik atau unggul dan individu juga mampu bertindak sesuai potensi dan kesadarannya tersebut, hal ini membuktikan adanya perkembangan positif sebagai individu (intelektual, emosional, sosial, etika dan perilaku).

Dari 200 mahasiswa sebagai informan penelitian dapat digeneralisasikan bahwa yang berkarakter baik atau unggul adalah seseorang yang berusaha melakukan hal-hal yang terbaik terhadap Tuhan YME, dirinya, sesama, lingkungan, bangsa dan negara serta dunia internasional pada umumnya dengan mengoptimalkan potensi (pengetahuan) dirinya dan disertai dengan kesadaran, emosi dan motivasinya (perasaannya). 
JURNAL CHRISTIAN HUMANIORA

Vol.4, No.1, May 2020, pp. 104-112

p-ISSN: 2598-6317- e-ISSN: 2599-196

Lalu, bagaimanakah hubunganya dengan pendidikan?. Menurut Ki Hajar Dewantara (Bapak Pendidikan Nasional Indonesia) menjelaskan tentang pengertian pendidikan yaitu: Pendidikan yaitu tuntutan di dalam hidup tumbuhnya anak-anak, adapun maksudnya, pendidikan yaitu menuntun segala kekuatan kodrat yang ada pada anak-anak itu, agar mereka sebagai manusia dan sebagai anggota masyarakat dapatlah mencapai keselamatan dan kebahagiaan setinggi-tingginya.

Menurut UU No. 20 tahun 2003 Pendidikan adalah usaha sadar dan terencana untuk mewujudkan suasana belajar dan proses pembelajaran agar peserta didik secara aktif mengembangkan potensi dirinya untuk memiliki kekuatan spiritual keagamaaan, pengendalian diri, kepribadian, kecerdasan, akhlak mulia, serta ketrampilan yang diperlukan dirinya, masyarakat, bangsa dan Negara.

Sedangkan pengertian pendidikan menurut $\mathrm{H}$. Horne, adalah proses yang terus menerus (abadi) dari penyesuaian yang lebih tinggi bagi makhluk manusia yang telah berkembang secara fisik dan mental, yang bebas dan sadar kepada vtuhan, seperti termanifestasi dalam alam sekitar intelektual, emosional dan kemanusiaan dari manusia.

Dari beberapa pengertian pendidikan menurut ahli tersebut maka dapat disimpulkan bahwa Pendidikan adalah Bimbingan atau pertolongan yang diberikan oleh orang dewasa kepada perkembangan anak untuk mencapai kedewasaannya dengan tujuan agar anak cukup cakap melaksanakan tugas hidupnya sendiri tidak dengan bantuan orang lain.

Pendidikan biasanya berawal saat seorang bayi itu dilahirkan dan berlangsung seumur hidup. Pendidikan bisa saja berawal dari sebelum bayi lahir seperti yang dilakukan oleh banyak orang dengan memainkan musik dan membaca kepada bayi dalam kandungan dengan harapan ia bisa mengajar bayi mereka sebelum kelahiran.

\section{Mahasiswa Berkarakter}

Mahasiswa berkarakter adalah mahasiswa yang memiliki wawasan kebangsaan biasanya mempunyai kepekaan sosial yang tinggi terhadap permasalahan yang sedang dihadapi oleh bangsa. Tidak hanya peka, tetapi setelah mengetahui masalah yang ada biasanya dia akan melakukan upaya untuk bisa memperbaikinya.

Hasil analisis data penelitian membuktikan bahwa mahasiswa berkarakter memiliki sikap dan perilaku yang baik, yang sesuai dengan norma yang berlaku dalam kehidupan sehari-hari. Erdasarkan hasil observasi, angket dan wawancara serta dokumentasi yang dilakukan selama penelitian berlangsung, adapun beberapa ciri mahasiswa berkarakter, yaitu:

a. Memiliki wawasan yang luas. 
Seorang mahasiswa dituntut untuk megerti dan menyadari keadaan di sekitarnya. Wawasan yang luas tidak hanya didapat dari ilmu yang dipelajari di perkuliahan saja, melainkan juga bisa didapat dari lingkungan sekitar.

b. Mampu membagi waktu

Masa kuliah merupakan masa-masa yang terdapat banyak waktu luang. Tinggal bagaimana mahasiswa itu sendiri dapat mengatur waktu yang dimilikinya, seperti untuk kuliah, organisasi, hobi, refreshing dan pacaran. Mahasiswa yang mampu membagi waktunya dengan baik, kelak akan menjadi seorang mahasiswa yang ideal

c. Memahami seluk beluk tempat menuntut ilmu.

Kampus, tempat mahasiswa menuntut ilmu menyimpan banyak cerita yang tidak akan terlupakan. Untuk menjadi mahasiswa ideal, mahasiswa harus mengerti seluk-beluk tempat menuntut ilmunya tersebut. Mulai dari dosen yang mengajar, ruangan belajar, fasilitas yang tersedia. Dengan mengetahui secara detail, mahasiswa akan mudah mengakses hal-hal yang berkaitan dengan kegiatan perkuliahan.

d. Pintar, rajin, aktif.

Tiga hal ini (pintar, rajin, aktif) adalah sifat wajib yang dimiliki oleh seorang mahasiswa ideal. Pintar dalam artian bahwa seorang mahasiswa pintar mengkondisikan diri dengan sekitarnya. Rajin berarti mengikuti kegiatan yang dipilihnya dengan rajin, tidak menjalani dengan setengah hati. Aktif yaitu turut serta dalam kegiatan-kegiatan positif universitas.

e. Pintar berdiskusi.

Sesuai dengan materi yang didapat pada LKMM pra dasar, mahasiswa itu harus memiliki sikap kritis. Dengan sikap kritis yang dimiliki, mahasiswa mempunyai kemampuan dalam berdiskusi. Kemampuan berdiskusi ini sangatlah berguna di masyarakat dan dunia kerja nantinya. Kemampuan berdiskusi yang baik di masa kuliah akan bermanfaat dalam menyampaikan pendapat di forum, sehingga tercapailah predikat mahasiswa ideal.

Ada beberapa macam karakter yang perlu dimiliki oleh tiap mahasiswa agar dapat menjadi pemimpin yang kelak dapat memimpin bangsa ini dengan baik. Karakter-karakter itu diantaranya adalah:
a. Beretika
b. Berwawasan luas
c. Bertanggung jawab
d. Pintar, rajin dan aktif
e. Memiliki reasa kasih sayang yang tinggi terhadap sesama.

Mahasiswa bukanlah orang terpandai di negeri ini, akan tetapi mahasiswa merupakan agent of change yang nantinya akan melanjutkan tongkat estafet pembangunan bangsa. Mahasiswa harusnya 
JURNAL CHRISTIAN HUMANIORA

Vol.4, No.1, May 2020, pp. 104-112

p-ISSN: 2598-6317- e-ISSN: 2599-196

memiliki suatu karakter yang dapat mendukung tercapainya tujuan bangsa, akan tetapi tanggung jawab besar yang dipikul oleh mahasiwa ini seakan-akan tidak diperhatikan dengan seksama oleh para mahasiswa. mahasiswa dikampus saat ini hanya bertumpu pada kegiatan perkuliahan semata tanpa memperdulikan apa yang telah dan akan terjadi pada lingkungan sekitarnya. Mahasiswa hanya dicekcoki dengan kegiatan perkuliahan seperti absensi, praktikum, ujian, KKN, seminar, skripsi dan wisuda. Hasil akhirnya, mahasiswa sekarang ini seperti tidak punya karakter sama sekali. Bahkan mahasiswa sudah tidak memiliki sopan santun kepada para dosen, mahasiswa sekarang lebih menyukai hidup dengan bebas, mengonsumsi obat-obatan terlarang, pergaulan bebas antara mahasiswa dengan mahasiswi, berdemonstrasi dengan tidak mengikuti peraturan yang berlaku bahkan hal terkecil seperti menyontek disaat ujian dianggap hal biasa, padahal menyontek merupakan salah satu hal yang tidak mengindahkan makna dari etika sebagai mahasiswa.

Mahasiswa dididik oleh institusi perguruan tinggi yang memiliki tujuan pendidikan. Secara tidak langsung, mahasiswa dituntut untuk ikut serta dalam mewujudkan tujuan pendidikan yang diusung oleh institusi tersebut. Menurut Kementrian Pendidikan dan Kebudayaan, tujuan pendidikan nasional adalah menciptakan lulusan yang memiliki kepribadaian dan karakter yang kuat dengan dilandasi keyakinan agama yang kokoh. Karakter memiliki cakupan makna yang luas.

Setelah lulus dari institusi pendidikan, mahasiswa yang memiliki wawasan kebangsaan diharapkan dapat membangun bangsa ini dengan bekal keilmuan yang telah dimilikinya. Ilmu yang didapat bukan hanya digunakan untuk memperkaya dirinya sendiri dan bukan pula digunakan untuk memajukan negara lain. Tetapi ilmu ayng didapatnya diharapkan dapat diaplikasikan dalam kehidupan bermasyarakat sehingga nantinya dapat meningkatkan kehidupan masyarakat yang semula kurang baik menjadi kehidupan yang lebih baik. Mahasiswa Indonesia seharusnya lebih tanggap dalam menghadapai masalah yang terjadi dalam kehidupan sekarang ini. Adapun beberapa masalah yang dihadapi sekarang ini yang membutuhkan peran serta dari mahasiswa.

\section{Masalah Etika}

Etika merupakan suatu ilmu yang membahas tentang benar dan salah suatu tindakan yang ditinjau dari kebiasaan dan norma-norma yang berlaku dalam kehidupan bermasyarakat. Peranan etika bagi aktivitas mahasiswa yaitu menjadi landasan dalam melakukan kegiatan yang tetap mengacu atau melihat nilai-nilai dan norma-norma, sehingga segala perbuatan dan tingkah laku kita dapat diterima masyarakat.

Mahasiswa sekarang merupakan mahasiswa-mahasiswa yang kritis dan berwawasan luas akan tetapi banyak diantara mahasiswa tersebut tidak memiliki etika yang baik. Mahasiswa tidak memiliki sopan dan santun kepada para dosen, mahasiswa lebih menyukai hidup dengan bebas, mengonsumsi obat-obatan terlarang, pergaulan bebas antara mahasiswa dengan mahasiswi, 
berdemonstrasi dengan tidak mengikuti peraturan yang berlaku. Inikah mahasiswa yang diharapkan akan menjadi kader penerus pembangngunan bangsa?

Apabila mahasiswa masih belum menyadari betapa pentingnya etika di dalam pembentukan karakter-karakter seorang penerus bangsa dan negara, akankah bangsa Indonesia untuk di masa yang akan datang di isi oleh penerus-penerus bangsa yang beretika?

Dari alah satu solusi konkrit yang dapat dilakukan yaitu memperbaiki etika para generasi muda, bukan hanya ditingkat universitas tapi juga di jenjang pendidikan sebelumnya. Etika bagi mahasiswa dapat menjadi alat kontrol di dalam melakukan suatu tindakan. Etika dapat menjadi gambaran bagi mahasiswa dalam mengambil suatu keputusan atau dalam melakukan sesuatu yang baik atau yang buruk. Oleh karena itu, makna etika harus lebih dipahami kembali dan diaplikasikan di dalam lingkungan mahasiswa yang realitanya lebih banyak mahasiswa yang tidak sadar dan tidak mengetahui makna etika dan peranan etika itu sendiri.

Mahasiswa sebagai penerus bangsa kiranya dapat memiliki etika yang baik sehingga kelak dapat menjadi pemimpin yang bisa memimpin bangsa ini dengan lebih adil dan lebih baik. Dengan adanya pemimpin yang beretika diharapkan segala masalah yang terjadi sekarang ini bisa dikurangi bahkan dihilangkan sehingga akan tercipta masyaraakat yang sejahtera, adil dan makmur.

\section{Masalah Pendidikan}

Lemahnya kualitas pendidikan bangsa Indonesia saat ini menjadi salah satu penyebeb utama kemiskinan dan kesengsaraan setiap warga Indonesia. Mengenai masalah pendidikan, tentunya mahasiswa mengetahui kondisi pendidikan formal di Indonesia karena mahasiswa pernah dan sedang menjadi objek pendidikan formal di suatu institusi pendidikan. Pendidikan formal di Indonesia dapat berjalan dengan baik apabila adanya sinergisme antara dua subjek. Pertama, pemerintah sebagai pemegang kebijakan negara dan yang kedua, sistem yang terlibat dalam proses pendidikan, misalnya sekolah dan kurikulum. Dengan demikian, bila saat ini pendidikan belum berjalan dengan baik, bisa diartikan ada kesalahan dalam kinerja pemerintah dan/atau sistem pendidikan yang sedang berjalan.

Bila kita mengasumsikan hal yang salah dari pendidikan Indonesia adalah sistemnya, mahasiswa sebagai objek pendidikan diharapkan bisa mengetahui apa saja yang salah dari sistem pendidikan di Indonesia. Setelah mengetahui bagian mana yang salah, mahasiswa bisa bertukar pikiran dan memutar otak untuk bisa mencari solusi yang konkret untuk mengatasinya.

Hasil angket dan interviu terhadap responden penelitian membuktikan bahwa salah satu solusi konkret yang bisa dijalankan oleh mahasiswa adalah membuat sistem pendidikan baru yang bisa menunjang sistem pendidikan yang sudah ada. Karena mahasiswa belum bisa menentukan kebijakan mengenai pendidikan seperti halnya pemerintah, sistem pendidikan yang dibuat oleh 
JURNAL CHRISTIAN HUMANIORA

Vol.4, No.1, May 2020, pp. 104-112

p-ISSN: 2598-6317- e-ISSN: 2599-196

mahasiswa bukan untuk menyaingi sistem pendidikan formal yang sudah ada, tetapi untuk mendukung dan melengkapinya.

Berdasarkan beberapa temuan penelitian yang telah diuraikan diatas, dapatlah kita lihat betapa mahasiswa sangatlah dibutuhkan dalam mengembangkan dan memajukan pendidikan dan kesejahteraan masyarakat Indonesia. Sekarang, sebagai seorang mahasiswa marilah sama-sama berusaha untuk menjadi lebih baik sehingga kelak diharapkan benar-benar bisa menjadi agent off change yang dapat mengubah bangsa Indonesia ini menjadi bangsa yang lebih baik.

\section{KESIMPULAN}

Mahasiswa sebagai agent of change merupakan salah satu pilar penting dalam membantu perkembangan dan pembangunan bangsa. Mahasiswa berkarakter adalah mahasiswa yang memiliki keberanian dan kemampuan untuk dapat menyampaikan aspirasinya dan dapat berguna bagi kehidupan bermasyarakat.

Masalah-masalah yang terjadi sekarang ini, seperti masalah etika, masalah pendidikan, masalah politik dan masalah kesejahteraan masyarakat merupakan sedikit masalah yang akan dihadapi mahsiswa dalam kehidupan nyata. Mahasiswa diharapkan dapat mengatasi masalahmasalah yang terjadi tersebut dengan mengaplikasikan ilmunya dalam kehidupan bermasyarakat sehingga dapat membantu meningkatkan kesejahteraan masyarakat.

\section{DAFTAR PUSTAKA}

Satyono, Ariesandie. 2006. Menjadi Orang Tua Efektif Dengan Hypnosis. Jakarta. PT Gramedia Pustaka Utama.

Bakry, Hasbullah. 2015. Sistematika Filsafat. Jakarta. Widjaya

Keraf, Sonny. 2014. Etika Lingkungan. Jakarta. Penerbit Buku Kompas

Bagus, Lorens.2012. Kamus Filsafat. Jakarta. PT Gramedia pustaka

Permen RI No. 30 Tahun 1990 Tentang Pendidikan Tinggi

Undang-Undang Republik Indonesia Nomor 12 Tahun 2012 Tentang Sistem Pendidikan Nasional

Aqila, Zainal dan Sujak. 2011. Panduan dan Aplikasi Pendidikan Karakter. Bandung. Yram Widya 